\title{
Transition Metal Complexes of Schiff Base Ligand Derived from Trimethoprim with Cyclohexanone: Synthesis, Characterization, Antimicrobial and Computational Studies
}

\section{Hussaini Garba ${ }^{1}$, Jamila Bashir Yakasai $^{2}$, Ibrahim Waziri ${ }^{3}$ and Ibraheem 0 Bisiriyu ${ }^{4}$}

${ }^{1}$ Department of Science Laboratory Technology, Ramat Polytechnic, Maiduguri, Borno State, Nigeria

${ }^{2}$ National Water Resources Institute, Mando, Kaduna State, Nigeria

${ }^{3}$ Department of Pure and Applied Chemistry, University of Maiduguri, Maiduguri, Nigeria

${ }^{4}$ Department of Chemical Sciences, Faculty of Science, University of Johannesburg, South Africa

*Corresponding Author: Hussaini Garba, Department of Science Laboratory Technology,

Ramat Polytechnic, Maiduguri, Borno State, Nigeria
Received: March 31, 2020

Published: April 29, 2020

(C) All rights are reserved by Hussaini Garba., et al.

\footnotetext{
Abstract

In this study, Metal (II) Complexes of Mn (II), Fe (III), Co (II) and Ni (II) with Schiff base ligand derived from Trimethoprim and Cyclohexanone were synthesized and characterized using various physic-chemical techniques such as: solubility, conductivity, melting point determination, UV/Vis and Fourier transform infrared, ${ }^{1} \mathrm{H}-\mathrm{NMR}$ and elemental analysis. On the basis of these characterizations, a six coordinated octahedral geometry has been proposed for all the complexes. The Schiff base ligand and its complexes were screened for their antimicrobial activity against some pathogenic microbial isolate and compared with the parent drug. The antimicrobial activity results showed the following trend: metal complexes > Schiff base ligands > Parent drugs. This suggests potential antimicrobials agents with broad spectrum activity. Computational studies further revealed that $\mathrm{M}-\mathrm{Cl}$ bond is responsible for the trend in antimicrobial properties among the complexes.

Keywords: Bacterial Resistance; Bacteria; Trimethoprim; Schiff Base; Complexes
}

\section{Introduction}

Bacterial resistance to antibiotics is a global public health concern that required urgent attention [1]. Without urgent and concerted action, we are moving toward an era in which common infections or minor diseases may become uncontrolled [2]. Centre for diseases control and prevention (CDC) has issued guideline for addressing the menace with emphasis on promoting and development of new antibiotics that can address the drug-resistance bacteria [3]. Generally, resistance occurs in nature. However, due to the inappropriate use of antibiotics in the area of treatment of diseases and prophylaxis bacteria are exposed to antibiotics more frequent and resistant become common [4]. There are various ways for which bacteria becomes resistance to antibiotics to antibiotics. The most common is through the process of natural selection [4]. In this regards, resistance is said to occur when not all bacteria are harmed by the antibiotics used for the treatment of particular infection and the surviving ones produce new generation of bacteria that will be resistance to that antibiotic [4]. Resistance also can emerge by mutations that alter the drug binding sites on molecular targets and by increasing expression of endogenous efflux pump [5]. Due to the increased rate of bacterial resistance to antibiotics, in February 2017, world health organization (WHO) released the list of bacteria that pose threat human health [6]. The list consist of Klebsiella, E. coli and Pseudomonas as multidrug resistant bacteria that pose a particular threat to public health and often cause severe and deadly infection [4]. Also, among the list includes Staphylococcus, Streptococcus and Salmonella [4]. It is very important to find compounds that can inhibit the growth of these bacteria. These bacteria are opportunistic and nosocomial pathogens and are multi-drug resistant. Pseudomonas aeruginosa has a highly impermeable outer membrane that prevents the uptake of most molecules including several antibiotics [7]. This result in difficulty of getting new antimicrobial agent that can prevent infection due Pseudomonas aeruginosa [8]. Staphylococcus aureus, a member of Gram-positive bacterium and also very common among people causes a lot infections, Staphylococcus aureus resistant to various antibiotics has resulted to the evolution of different strains of bacteria such as methicillin-resistance Staphylococcus aureus (MRSA) [9]. Although, Staphylococcus aureus drug-resistant has reduced significantly, but MRSA resistant strains is still a major threat to the public health [10]. Recently, have reported the synthesis of Mn (II) and Fe (III) with Schiff base derived from trimethoprim with salicylaldehyde and benzaldehyde as potential antimicrobial agent and were found to showed good activity on both Gram-positive and Gram-negative bacteria [11].

Trimethoprim, systematically named as 2,4-diamine pyrimidine -5-(3, 4,5-Trimethoxybenzyl) is on the World Health Organization's list of essential medicines, the most important medications needed in a basic health system [12]. Trimethoprim was commonly used in a 1:5 combination with sulfamethoxazole, a sulfonamide antibiotic. 
This combination, also known as co-trimoxazole, results in an in vitro synergistic antibacterial activity [13]. This drug combination also reduces the development of resistance that is seen when either drug is used alone [14]. Trimethoprim has potential binding sites for carbonyl functional group to form a Schiff base (or imine or azomethine).

In general, the addition of an amine to a compound containing a carbonyl functional group, aldehydes or ketones produces an imine (Schiff base). The former gives an aldimine while the later produces a ketoimine. Schiff bases are studied widely due to their synthetic flexibility, selectivity and sensitivity toward the central metal atom, their structural similarities with natural biological compounds and also due to presence of azomethine group $(-\mathrm{N}=\mathrm{CH})$ which imports in elucidating the mechanism of transpiration and racemization reaction biologically [15]. The interaction between metal ions and such biologically active ligands (Schiff base) represents an important route in designing new metal-based antibacterial, antifungal and anticancer therapies against different kinds of bacteria, fungi and viruses that are resistant to the conventional drugs [16].

Schiff base-transition metal complexes have gain significant attention in recent time due to their stability, ease of modification and enormous biological properties [17]. Herein, we report the synthesis, characterization and antimicrobial studies of transition metal complexes of Schiff base derived from trimethoprim with $\mathrm{Cy}$ clohexanone.<smiles></smiles>

Figure 1a: Trimethoprim.<smiles>O=C1CCCCC1</smiles>

Figure 1b: Cyclohexanone.

\section{Materials and Methods}

Materials and reagents

All reagents were purchased from Sigma-Aldrich, through Bristol Scientific Company, Lagos, and all were of Analytical grade (AR) and were used without further purification. They includes: trimethoprim, cyclohexane, manganese (II) chloride tetra hydrate, cobalt (II) chloride hexahydrate, nickel (II) chloride hexahydrate and iron (III) chloride hexahydrate.

\section{Physical measurements}

${ }^{1} \mathrm{H}$-NMR and ${ }^{13} \mathrm{C}$-NMR spectrum of the ligand was recorded on Bruker $400 \mathrm{MHz}$ NMR instrument and using TMS as internal standard at the department of chemical sciences, university of Johannesburg, South Africa. Electronic spectra of the metal complexes and the ligand in DMSO were recorded on Shimadzu UV - 1900, UVVis spectrometer. The decomposition temperatures of the complexes were determined on Polmon instrument (model number-96). IR spectra of the compounds were recorded using $\mathrm{KBr}$ pellets in the range (400 - 500) $\mathrm{cm}^{-1}$ On Perkin Elmer Infrared model 337. The percentage (\%) of Mn, Fe, Co and Ni were determined by EDTA complexometric titration.

\section{Antimicrobial screening}

The standard drug (trimethoprim), Schiff base and the metal complexes were screened against different strains of bacteria, which include both Gram-positive and Gram-negative. The antimicrobial screening was done using disc diffusion method [18]. The bacterial used are Staphylococcus aureus, Bacillus subtilis, Streptococcus pyogenes sand Corynebacteria species (Gram-positive) and Escherichia coli, Shigella dysenteriae, Salmonella typhi, Klebsiella pneumoniae and Pseudomonas aeruginosa (Gram-negative). The cultures of test organism were kept on nutrient agar culture media and subculture before testing.

\section{Statistical analysis}

The data obtained were analyzed using one way ANOVA. The results were recorded as MEAN \pm SEM on GraphPad inStat, 2000 .

\section{Synthesis of Schiff base ligand (HL)}

Trimethoprim (2,4-diamine pyrimidine-5-(3,4,5-trimethoxybenzyl) (5g, $17.22 \mathrm{mmol}$, 1eq) was dissolved in $30 \mathrm{~mL}$ of hot methanol to which Cyclohexanone (1.72g, $17.22 \mathrm{mmol}$, 1eq) was added, and the mixture was refluxed for $4 \mathrm{hrs}$. The white precipitate formed was filtered, washed with hexane, dried and weighed. (3.86g, $11.29 \mathrm{mmol}, 65.56 \%$ ) (Scheme 1). M.p.: $232-235^{\circ} \mathrm{C} ;{ }^{1} \mathrm{H}$ NMR (400 MHz, DMSO- $\left.{ }_{\mathrm{d} 6}\right): \delta 1.64-1.67(\mathrm{~ms}, 6 \mathrm{H}, \mathrm{J}=12 \mathrm{~Hz}), 2.32-2.34$ $(\mathrm{ms}, 4 \mathrm{H}, \mathrm{J}=8 \mathrm{~Hz}), 3.83\left(\mathrm{~s}, 9 \mathrm{H},\left(\mathrm{OCH}_{3}\right)_{3}\right), 3.96\left(\mathrm{~s}, 2 \mathrm{H}, \mathrm{CH}_{2}\right), 6.46(\mathrm{~s}$, $2 \mathrm{H}, \mathrm{Ar}$ ), 7.50 (s, 1H, Ar), 8.50 (br, 2H, NH $\left.{ }_{2}\right) ;{ }^{13} \mathrm{C}\{\mathrm{H}\} \mathrm{NMR}:(101 \mathrm{MHz}$, DMSO- $_{\mathrm{d} 6}$ ): $\delta 25.5,27.4,30.6,36.6,187.0$ (cyclohexane); $37.3\left(\mathrm{CH}_{2}\right)$; $56.1\left(\mathrm{OCH}_{3}\right)_{2} 60.8\left(\mathrm{OCH}_{3}\right) ; 102.9,113.3,130.5,136.2,152.8,157.1$, 157.9, 162. 2 (Ar). Anal. Calculated for $\mathrm{C}_{20} \mathrm{H}_{26} \mathrm{~N}_{4} \mathrm{O}_{3}: \mathrm{C}, 64.84 ; \mathrm{H}, 7.07$; N, 15.12; found; C, 64.68; H, 7.03; N, 15.10; ESI-TOF-HRMS: [M+H] ${ }^{+}$ calculated for $\mathrm{C}_{20} \mathrm{H}_{26} \mathrm{~N}_{4} \mathrm{O}_{3}: 371.2005$, Found 371.4350 .

General procedure for the synthesis of trimethoprim schiff base metal complexes

In the preparation of the complexes, metal salts: Mn (II), Fe (III), Co (II) and Ni (II) were added to the ligand solution in a 1:2 mole ratio (metal-ligand) using required quantity of methanol. Methanolic solution of the ligand (HL) $(0.5 \mathrm{~g}, 1.35 \mathrm{mmol}, 2 \mathrm{eq})$ and methanolic solution of $\mathrm{NiCl}_{2} \cdot 6 \mathrm{H}_{2} \mathrm{O}, \mathrm{MnCl}_{2} .4 \mathrm{H}_{2} \mathrm{O}$ and $\mathrm{CoCl}_{2} .6 \mathrm{H}_{2} \mathrm{O}(0.11 \mathrm{~g}, 0.67$ $\mathrm{mmol}$ ), and $\mathrm{FeCl}_{3} \cdot 6 \mathrm{H}_{2} \mathrm{O}(0.14 \mathrm{~g}, 0.67 \mathrm{mmol})$ were mixed together with continuous stirring until the complex compound precipitated out. The colored product formed was separated by filtration, washed with distilled water and methanol, and dried under vacuum in a desiccator containing calcium chloride. Recrystalisation from hot methanol gave the metal complexes (Scheme 2).

[Mn(HL) ${ }_{2} \mathrm{Cl}_{2}$ ]: Anal. Calculated for $\mathrm{C}_{40} \mathrm{H}_{52} \mathrm{Cl}_{2} \mathrm{MnN}_{8} \mathrm{O}_{6}: \mathrm{C}, 55.43 ; \mathrm{H}$, 6.05; N, 12.93; found; C, 55.10; H, 6.02; N, 12.76; ESI-TOF-HRMS: [M $+\mathrm{H}]^{+}$calculated for $\mathrm{C}_{40} \mathrm{H}_{52} \mathrm{Cl}_{2} \mathrm{MnN}_{8} \mathrm{O}_{6}: 867.2738$, Found 867.2767.

[(Fe(HL)2Cl2)]Cl: Anal. Calculated for $\mathrm{C}_{40} \mathrm{H}_{52} \mathrm{Cl}_{3} \mathrm{FeN}_{8} \mathrm{O}_{6}: \mathrm{C}, 33.20 ; \mathrm{H}$, 5.80; N, 12.41; found; C, 33.15; H, 5.63; N, 12.36; ESI-TOF-HRMS: $[\mathrm{M}+\mathrm{H}]^{+}$calculated for $\mathrm{C}_{40} \mathrm{H}_{52} \mathrm{Cl}_{3} \mathrm{FeN}_{8} \mathrm{O}_{6}: 903.2395$, Found 902.2425 . 


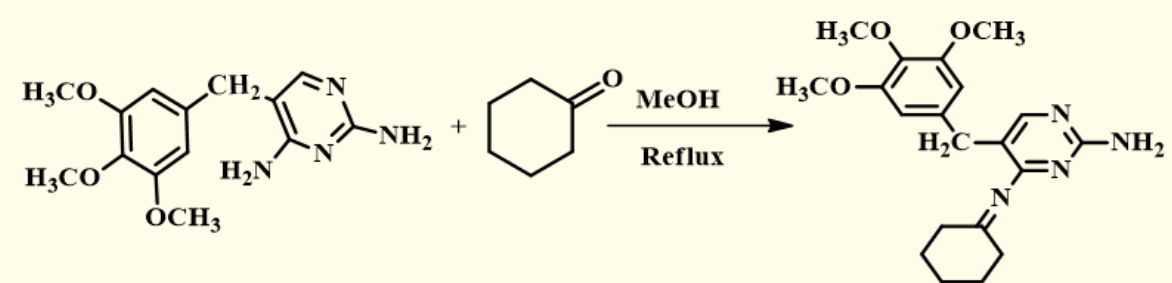

Scheme 1: Synthesis of Schiff base ligand (HL).

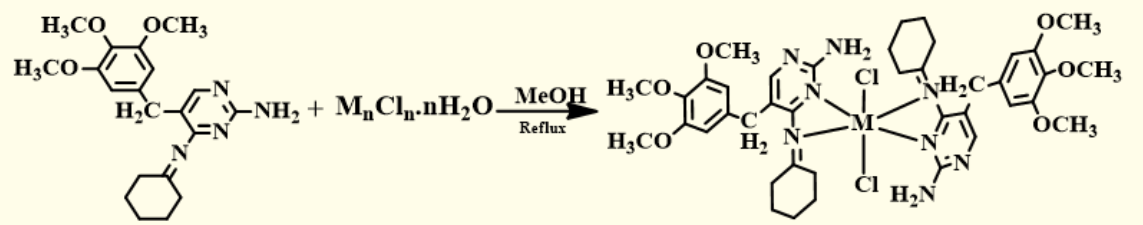

Scheme 2: Synthesis of metal complexes. M = Ni (II), Co (II), Mn (II) and Fe (III) and n = 1 - 6.

[Co(HL)2Cl2]: Anal. Calculated for $\mathrm{C}_{40} \mathrm{H}_{52} \mathrm{Cl}_{2} \mathrm{CoN}_{8} \mathrm{O}_{6}: \mathrm{C}, 55.18 ; \mathrm{H}$, 6.02; N, 12.87; found; C, 55.15; H, 5.98; N, 12.76; ESI-TOF-HRMS: [M $+\mathrm{H}]^{+}$calculated for $\mathrm{C}_{40} \mathrm{H}_{52} \mathrm{Cl}_{2} \mathrm{CoN}_{8} \mathrm{O}_{6}: 871.2689$, Found 871.2719.

[Ni(HL)2Cl2]: Anal. Calculated for $\mathrm{C}_{40} \mathrm{H}_{52} \mathrm{Cl}_{2} \mathrm{~N}_{8} \mathrm{NiO}_{6}: \mathrm{C}, 55.19 ; \mathrm{H}$, 6.02; N, 12.87; found; C, 55.13; H, 5.85; N, 12.73; ESI-TOF-HRMS: [M $+\mathrm{H}]^{+}$calculated for $\mathrm{C}_{40} \mathrm{H}_{52} \mathrm{Cl}_{2} \mathrm{~N}_{8} \mathrm{NiO}_{6}: 870.2711$, Found 870.2740.

\section{Results and Discussion}

The ligand and its complexes gave a good yield of $65-97 \%$. All the complexes have sharp melting points ranging from $255^{\circ} \mathrm{C}$ to $285^{\circ} \mathrm{C}$, which suggests that the complexes are probably pure. The melting points of the complexes are higher than their ligand and the parent drug probably due to complexation [19]. These high

\begin{tabular}{|l|c|c|c|c|c|c|}
\hline Compounds & Molecular formula & Colour & Melting points oC & Yield (\%) & Molar Conductivity (Scm $\left.{ }^{2} \mathbf{m o l}^{-1}\right)$ & Metal \% \\
\hline & & & & & & Found (calc.) \\
\hline $\mathrm{HL}$ & 370.46 & White & $232-235$ & 72.69 & - & - \\
\hline$\left[\mathrm{Mn}(\mathrm{HL})_{2} \mathrm{Cl}_{2}\right]$ & 866.83 & Dark brown & $255-258$ & 89.09 & $11 \times 10^{-4}$ & $6.31(6.34)$ \\
\hline$\left[\mathrm{Fe}(\mathrm{HL})_{2} \mathrm{Cl}_{2}\right] \mathrm{Cl}$ & 903.22 & Yellow Ocher & $283-285$ & 97.28 & $28 \times 10^{-4}$ & $5.92(6.18)$ \\
\hline$\left[\mathrm{Co}(\mathrm{HL})_{2} \mathrm{Cl}_{2}\right]$ & 870.85 & Light Green & $274-277$ & 93.05 & $10 \times 10^{-4}$ & $6.77(6.77)$ \\
\hline$\left[\mathrm{Ni}(\mathrm{HL})_{2} \mathrm{Cl}_{2}\right]$ & 870.64 & Buff & $256-258$ & 96.22 & $9 \times 10^{-4}$ & $6.48(6.74)$ \\
\hline
\end{tabular}

Table 1: Physical characteristics of the ligand and its metal complexes.

Key: HL: Schiff Base Ligand.

melting points revealed the stability of the complex compounds toward air and moisture [20]. The complexes are non-hygroscopic/ solids. The complexes prepared have various colours ranging from dark brown, yellow ocher, light green and buff which indicate the properties of transition metal compounds [21].

\section{Solubility and conductivity measurements}

The molar conductance values measured in methanol solution $\left(10^{-3} \mathrm{M}\right)$ for the complexes were in the range $0.9-0.28 \mathrm{Scm}^{2} \mathrm{~mol}^{-1}$ : Based on these results, the complexes can be said to be non electrolytes, since a value in the range $75-90 \mathrm{Scm}^{2} \mathrm{~mol}^{-1}$ is expected for a 1:1 electrolyte $[22,23]$. The complexes are soluble in common organic solvents but insoluble in water. The insolubility of these complexes in water and their non- electrolytic nature suggests that they are probably non-polar and further provide evidence for covalence of the compounds [20].

\section{Infrared spectra}

To ascertain the bonding of the ligands to the metal ion, a careful comparison of the infrared spectroscopy of ligands and complexes was done (Table 2). The relevant vibrational bands of the free ligands and the complexes are in the region $400-4000 \mathrm{~cm}^{-1}[24]$. IR band of the ligands and their metal complexes have been assigned based on data available in the literature and all the spectral data were consistent with the structure of the compounds. Comparative studies of IR spectra of the ligands and their complexes indicate that several peaks found in the ligands are shifted, or completely absent in the spectra of the complexes. The $\mathrm{N}-\mathrm{H}$ stretching frequencies of the pyrimidine $\mathrm{NH}_{2}$ in the trimethoprim Schiff bases shifted slightly in the metal complexes. The slight shift is ascribed to hydrogen bonding and other non-covalent interactions in the metal complexes.

It was observed in the region, 3500-3300 $\mathrm{cm}^{-1}$, these bands shifted significantly with respect to those of the ligand as shown in table 2. This confirms that the metal ions have coordinated to the trimethoprim Schiff bases through the two $\mathrm{N}$ atoms that belong to $-\mathrm{NH}_{2}$ and - $\mathrm{NH}$ groups [25]. The IR data of each ligand confirms the formation of imines bond $v(-\mathrm{C}=\mathrm{N}-\mathrm{H})$ and the absence of carbonyl bond $v(\mathrm{C}=0)$ [26]. A sharp frequency band at $1643 \mathrm{~cm}^{-1}$ in trim- 


\begin{tabular}{|l|c|c|c|c|}
\hline Compounds & $\boldsymbol{v}\left(\mathbf{N H}_{2}\right)$ & $\boldsymbol{v}(\mathbf{C}=\mathbf{N})$ & $v(\mathbf{C}-\mathbf{N})$ & $v(\mathbf{N}-\mathbf{M})$ \\
\hline $\mathrm{HL}$ & $3406_{\mathrm{br}}$ & $1643_{\mathrm{m}}$ & $1481_{\mathrm{m}}$ & - \\
\hline$\left[\mathrm{Mn}(\mathrm{HL})_{2} \mathrm{Cl}_{2}\right]$ & $3402_{\mathrm{s}}$ & $1643_{\mathrm{sh}}$ & $1496_{\mathrm{m}}$ & $524_{\mathrm{s}}$ \\
\hline$\left[\mathrm{Fe}(\mathrm{HL})_{2} \mathrm{Cl}_{2}\right] \mathrm{Cl}$ & $3402_{\mathrm{vs}}$ & $1654_{\mathrm{s}}$ & $1496_{\mathrm{m}}$ & $489_{\mathrm{s}}$ \\
\hline$\left[\mathrm{Co}(\mathrm{HL})_{2} \mathrm{Cl}_{2}\right]$ & $3441_{\mathrm{sh}}$ & $1614_{\mathrm{sh}}$ & $1456_{\mathrm{sh}}$ & $509_{\mathrm{s}}$ \\
\hline$\left[\mathrm{Ni}(\mathrm{HL})_{2} \mathrm{Cl}_{2}\right]$ & $3402_{\mathrm{vs}}$ & $1643_{\mathrm{s}}$ & $1489_{\mathrm{m}}$ & $478_{\mathrm{sh}}$ \\
\hline
\end{tabular}

Table 2: Relevant infrared spectra of the ligands and their metal complexes $\left(\mathrm{cm}^{-1}\right)$.

Key: br: Broad, w: Weak, sh: Sharp, s: Strong, m: Medium, vs: Very Strong.

ethoprim Schiff base assigned to the pyrimidine nitrogen (azomethine) $v(\mathrm{C}=\mathrm{N})$ [27], shifted in the ligands HL as well as in the metal complexes, this confirmed that the metal ions have coordinated directly to the imine nitrogen atom $[28,29]$. IR of the complexes also showed new low intensity bands, called the non-ligand band in the far infrared region: $478-524 \mathrm{~cm}^{-1}$, which could be assigned to $v$ (M-N) modes [28-30]. It may be noted that, these vibrational bands were absent in the spectra of the ligands, which further provide evidence for the occurrence of coordination [29]. The appearance of $v(\mathrm{M}-\mathrm{N})$ vibrations supports the involvement of nitrogen atom in complexation with metal ions under investigation [31-33].

\section{Electronic spectra}

The electronic spectra of the ligand (HL) shows absorption bands in the UV region which are due to $\pi-\pi^{*}$ transitions of the ligand. The broad band observed in the visible region of the electronic spectra is due to $\mathrm{d}$ - $\mathrm{d}$ transitions of the metal ion table 3 [34].

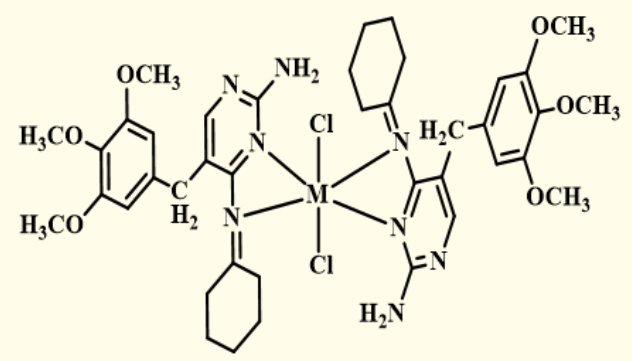

Figure 2a: Structure of the Metal complexes (M= Mn, Co, Ni).

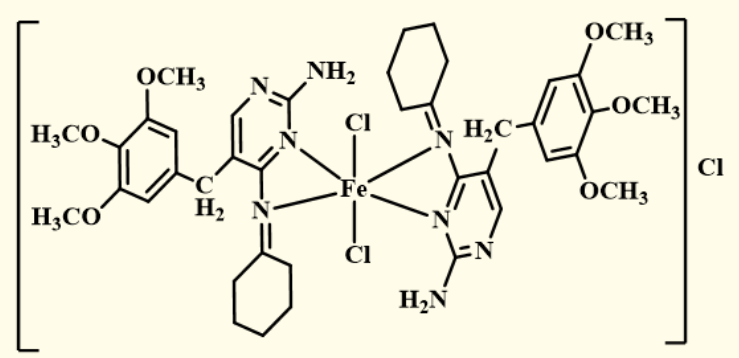

Figure 2b: Structure of the Fe (III) Metal complex.

\section{Antibacterial activity}

The synthesized metal complexes, ligand and the antibiotic Trimethoprim were screened in vitro for their antimicrobial activity against five gram-negative (Escherichia coli, Shigella dysenteriae, Salmonella typhi, Klebsiella pneumoniae and Pseudomonas aeruginosa), four Gram-positive (Staphylococcus aureus, Bacillus subtilis,

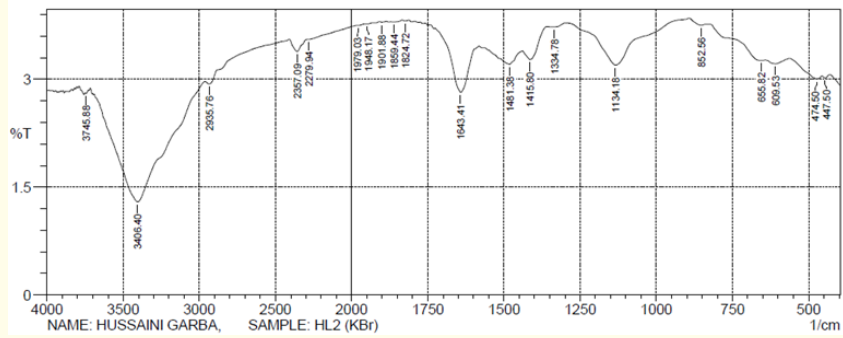

Figure 3: IR spectra of the Schiff base ligand (HL).

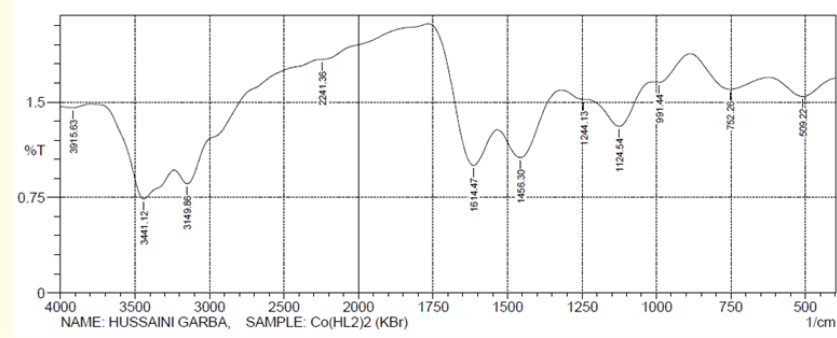

Figure 4: IR spectra of Co (HL) $\mathrm{Cl}_{2}$.

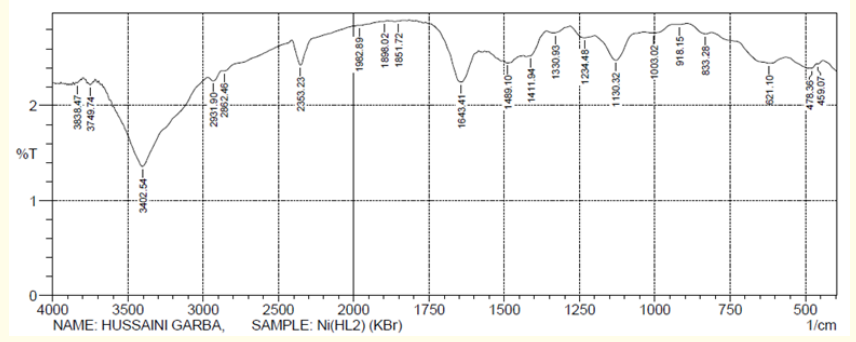

Figure 5: IR spectra of $\mathrm{Ni}(\mathrm{HL})_{2} \mathrm{Cl}_{2}$.

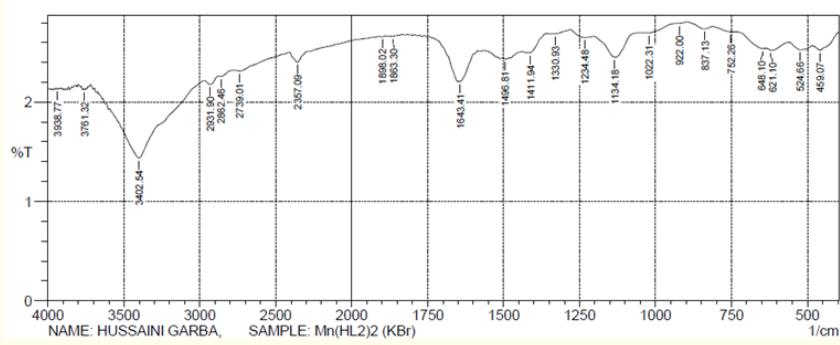

Figure 6: IR spectra of $\mathrm{Mn}(\mathrm{HL})_{2} \mathrm{Cl}_{2}$.

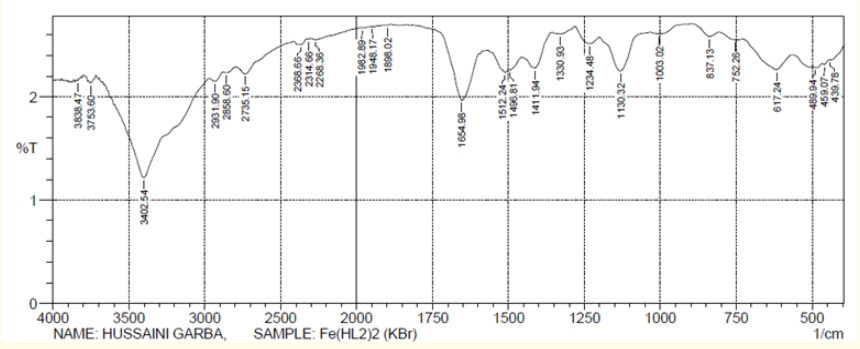

Figure 7: IR spectra of $\mathrm{Mn}(\mathrm{HL})_{2} \mathrm{Cl}_{3}$.

Streptococcus pyogenes and Corynebacteria species) and a fungal species (Candida albicans) associated with urinary tract infection. The experiments were conducted in three different concentrations and the results were expressed as (Mean \pm SEM) values in table 


\begin{tabular}{|l|c|c|c|}
\hline Compounds & $\boldsymbol{K}_{\text {max }}$ (nm) & Band maxima (cm (c) $^{-1}$ & Assignments \\
\hline $\mathrm{HL}$ & 370 & 27027 & $\mathrm{n} \rightarrow \pi^{*}$ \\
& 260 & 39462 & $\pi \rightarrow \pi^{*}$ \\
\hline$\left[\mathrm{Mn}(\mathrm{HL})_{2} \mathrm{Cl}_{2}\right]$ & 420 & 23809 & ${ }^{6} \mathrm{~A}_{1 \mathrm{~g}} \rightarrow{ }^{4} \mathrm{E}_{2 \mathrm{~g}}$ \\
& 310 & 32258 & $\mathrm{IL}$ \\
\hline$\left[\mathrm{Fe}(\mathrm{HL})_{2} \mathrm{Cl}_{2}\right] \mathrm{Cl}$ & 490 & 20408 & ${ }^{6} \mathrm{~A}_{1 \mathrm{~g}} \rightarrow{ }^{4} \mathrm{~T}$ \\
& 370 & 27027 & ${ }^{2 \mathrm{gLCT}}$ \\
\hline$\left[\mathrm{Co}(\mathrm{HL})_{2} \mathrm{Cl}_{2}\right]$ & 670 & 14925 & ${ }^{4} \mathrm{~T}_{1 \mathrm{~g}} \rightarrow{ }^{4} \mathrm{~A}_{2 \mathrm{~g}}$ \\
& 440 & 22727 & ${ }^{4} \mathrm{~T}_{1 \mathrm{~g}} \rightarrow{ }^{4} \mathrm{~T}_{2 \mathrm{~g}}$ \\
\hline$\left[\mathrm{Ni}(\mathrm{HL})_{2} \mathrm{Cl}_{2}\right]$ & 610 & 16393 & ${ }^{3} \mathrm{~A}_{2 \mathrm{~g}} \rightarrow{ }^{3} \mathrm{~T}_{2 \mathrm{~g}}$ \\
& 380 & 26316 & ${ }^{\mathrm{MLCT}}$ \\
\hline
\end{tabular}

Table 3: Data for the electronic absorption spectra of the ligands and their complexes.
4. MIC and MBC were also conducted the results shown in table 5 and 6 below. The result shows that the compounds have no activity against Staphylococcus aureus, Escherichia coli, Salmonella typhi, Klebsiella pneumoniae and Pseudomonas aeruginosa. The complexes show varying activities against Staphylococcus aureus, Bacillus subtilis, Corynebacteria species, Shigella dysenteriae and Candida albicans. The complexes are more active than the parent ligand because the metal complex may serve as a vehicle for activation of ligand as the principle cytotoxic species [35]. It is known that chelating tends to make the metal complex acts as more powerful and potent bactericidal agents, thus killing more of the bacteria than the ligand [36]. There are other factors which also increase

\begin{tabular}{|c|c|c|c|c|c|c|c|c|c|c|c|}
\hline \multirow[b]{2}{*}{ 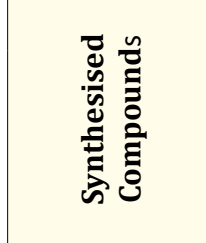 } & \multirow[b]{2}{*}{ 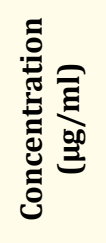 } & \multicolumn{10}{|c|}{ Antimicrobial activity with zone of inhibition (mm) } \\
\hline & & 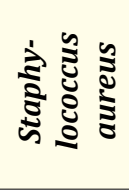 & 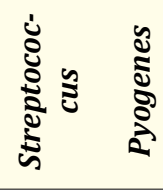 & 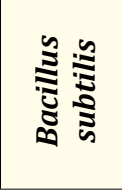 & 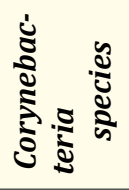 & 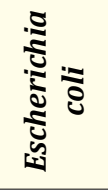 & 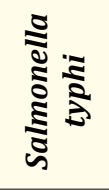 & 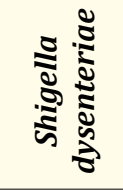 & 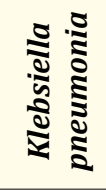 & 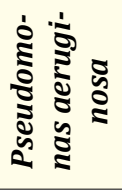 & 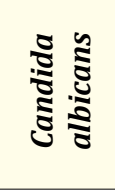 \\
\hline \multirow{3}{*}{$\mathrm{HL}$} & 30 & $\begin{array}{c}0.00 \pm \\
0.00\end{array}$ & $\begin{array}{c}30.30 \pm \\
0.58^{\mathrm{a}}\end{array}$ & $\begin{array}{c}15.30 \pm \\
0.58^{\mathrm{b}}\end{array}$ & $\begin{array}{c}27.30 \pm \\
0.58^{\mathrm{b}}\end{array}$ & $\begin{array}{c}0.00 \pm \\
0.00\end{array}$ & $\begin{array}{c}0.00 \pm \\
0.00\end{array}$ & $\begin{array}{c}13.30 \pm \\
0.58^{\mathrm{a}}\end{array}$ & $\begin{array}{c}0.00 \pm \\
0.00\end{array}$ & $\begin{array}{c}0.00 \pm \\
0.00\end{array}$ & $\begin{array}{c}18.70 \pm \\
1.15^{\mathrm{a}, \mathrm{a}^{\prime}}\end{array}$ \\
\hline & 20 & $\begin{array}{c}0.00 \pm \\
0.00\end{array}$ & $\begin{array}{c}26.00 \pm \\
0.00^{\mathrm{a}, \mathrm{a}^{\prime}} \\
\end{array}$ & $\begin{array}{c}12.00 \pm \\
0.00^{\mathrm{c}}\end{array}$ & $\begin{array}{r}22.70 \pm \\
0.58^{\text {a.a. }} \\
\end{array}$ & $\begin{array}{c}0.00 \pm \\
0.00\end{array}$ & $\begin{array}{c}0.00 \pm \\
0.00\end{array}$ & $\begin{array}{c}10.30 \pm \\
0.58^{\mathrm{b}, \mathrm{b}^{\prime}}\end{array}$ & $\begin{array}{c}0.00 \pm \\
0.00\end{array}$ & $\begin{array}{c}0.00 \pm \\
0.00\end{array}$ & $\begin{array}{r}13.30 \pm \\
0.58^{\mathrm{b}, \mathrm{b}^{\prime}}\end{array}$ \\
\hline & 10 & $\begin{array}{c}0.00 \pm \\
0.00\end{array}$ & $\begin{array}{l}21.30 \pm \\
0.58^{b^{a}, b^{\prime}}\end{array}$ & $\begin{array}{l}9.00 \pm \\
0.00^{\text {ad }}\end{array}$ & $\begin{array}{c}18.30 \pm \\
0.58^{\mathrm{c}, c^{\prime}}\end{array}$ & $\begin{array}{c}0.00 \pm \\
0.00\end{array}$ & $\begin{array}{c}0.00 \pm \\
0.00\end{array}$ & $\begin{array}{l}8.00 \pm \\
0.58^{\mathrm{c}, \mathrm{c}^{\prime}}\end{array}$ & $\begin{array}{c}0.00 \pm \\
0.00\end{array}$ & $\begin{array}{c}0.00 \pm \\
0.00\end{array}$ & $\begin{array}{c}9.70 \pm \\
0.58^{\mathrm{c}}\end{array}$ \\
\hline \multirow{3}{*}{$\mathrm{Mn}(\mathrm{HL})_{2} \mathrm{Cl}_{2}$} & 30 & $\begin{array}{c}0.00 \pm \\
0.00\end{array}$ & $\begin{array}{c}30.30 \pm \\
0.58^{\mathrm{a}, \mathrm{a}^{\prime}}\end{array}$ & $\begin{array}{c}17.30 \pm \\
0.58^{\mathrm{e}}\end{array}$ & $\begin{array}{c}19.00 \pm \\
0.00^{\mathrm{d}, c^{\prime}}\end{array}$ & $\begin{array}{c}0.00 \pm \\
0.00\end{array}$ & $\begin{array}{c}0.00 \pm \\
0.00\end{array}$ & $\begin{array}{c}18.30 \pm \\
0.58^{\mathrm{d}, \mathrm{d}^{\prime}}\end{array}$ & $\begin{array}{c}0.00 \pm \\
0.00\end{array}$ & $\begin{array}{c}0.00 \pm \\
0.00\end{array}$ & $\begin{array}{r}21.70 \pm \\
0.58^{\mathrm{d}, \mathrm{d}^{\prime}}\end{array}$ \\
\hline & 20 & $\begin{array}{c}0.00 \pm \\
0.00\end{array}$ & $\begin{array}{c}25.00 \pm \\
0.00^{c, a}, b^{\prime} b^{\prime} c^{\prime} \\
\end{array}$ & $\begin{array}{c}13.30 \pm \\
0.58^{\mathrm{f}} \\
\end{array}$ & $\begin{array}{c}14.70 \pm \\
0.58^{\mathrm{e}, e^{\prime}}\end{array}$ & $\begin{array}{c}0.00 \pm \\
0.00\end{array}$ & $\begin{array}{c}0.00 \pm \\
0.00\end{array}$ & $\begin{array}{c}13.30 \pm \\
0.58^{\mathrm{a}}\end{array}$ & $\begin{array}{c}0.00 \pm \\
0.00 \\
\end{array}$ & $\begin{array}{c}0.00 \pm \\
0.00\end{array}$ & $\begin{array}{c}17.00 \pm \\
0.00^{\mathrm{e}, \mathrm{e}^{\prime}}\end{array}$ \\
\hline & 10 & $\begin{array}{c}0.00 \pm \\
0.00\end{array}$ & $\begin{array}{c}20.30 \pm \\
0.58^{\mathrm{d}, \mathrm{b}^{\prime}}\end{array}$ & $\begin{array}{l}9.70 \pm \\
0.58^{\mathrm{a}, \mathrm{a}^{\prime}}\end{array}$ & $\begin{array}{c}11.70 \pm \\
0.58^{\mathrm{f}}\end{array}$ & $\begin{array}{c}0.00 \pm \\
0.00\end{array}$ & $\begin{array}{c}0.00 \pm \\
0.00\end{array}$ & $\begin{array}{c}9.00 \pm \\
0.00^{\mathrm{e}, \mathrm{b}^{\prime}, \mathrm{c}^{\prime}}\end{array}$ & $\begin{array}{c}0.00 \pm \\
0.00\end{array}$ & $\begin{array}{c}0.00 \pm \\
0.00\end{array}$ & $\begin{array}{r}12.70 \pm \\
0.58^{\mathrm{f}, \mathrm{a}^{\prime}} \\
\end{array}$ \\
\hline \multirow{3}{*}[\mathrm{Fe}(\mathrm{HL})_{2}\mathrm{Cl}_{2}]{$\mathrm{Cl}$} & 30 & $\begin{array}{c}0.00 \pm \\
0.00\end{array}$ & $\begin{array}{c}38.70 \pm \\
0.58^{e^{e} e^{\prime}}\end{array}$ & $\begin{array}{c}0.00 \pm \\
0.00\end{array}$ & $\begin{array}{c}27.30 \pm \\
0.58^{\mathrm{a}, \mathrm{a}^{\prime}}\end{array}$ & $\begin{array}{c}0.00 \pm \\
0.00\end{array}$ & $\begin{array}{c}0.00 \pm \\
0.00\end{array}$ & $\begin{array}{c}30.70 \pm \\
0.58^{\mathrm{f}}\end{array}$ & $\begin{array}{c}0.00 \pm \\
0.00\end{array}$ & $\begin{array}{c}0.00 \pm \\
0.00\end{array}$ & $\begin{array}{r}24.30 \pm \\
0.58^{\mathrm{g}, \mathrm{g}^{\prime}}\end{array}$ \\
\hline & 20 & $\begin{array}{c}0.00 \pm \\
0.00\end{array}$ & $\begin{array}{l}34.30 \pm \\
0.58^{\mathrm{a}, \mathrm{a}^{\prime}, e^{\prime}}\end{array}$ & $\begin{array}{c}0.00 \pm \\
0.00\end{array}$ & $\begin{array}{c}21.70 \pm \\
0.58^{\text {gat }}\end{array}$ & $\begin{array}{c}0.00 \pm \\
0.00\end{array}$ & $\begin{array}{c}0.00 \pm \\
0.00\end{array}$ & $\begin{array}{c}26.70 \pm \\
0.58^{\mathrm{g}}\end{array}$ & $\begin{array}{c}0.00 \pm \\
0.00\end{array}$ & $\begin{array}{c}0.00 \pm \\
0.00\end{array}$ & $\begin{array}{r}20.00 \pm \\
0.00^{\mathrm{a}, \mathrm{d}^{\prime}} \\
\end{array}$ \\
\hline & 10 & $\begin{array}{c}0.00 \pm \\
0.00\end{array}$ & $\begin{array}{l}30.00 \pm \\
0.00^{\mathrm{a}, \mathrm{a}^{\prime} \mathrm{b}^{\prime}}\end{array}$ & $\begin{array}{c}0.00 \pm \\
0.00\end{array}$ & $\begin{array}{c}15.70 \pm \\
0.58^{\mathrm{h}, \mathrm{e}^{\prime}}\end{array}$ & $\begin{array}{c}0.00 \pm \\
0.00\end{array}$ & $\begin{array}{c}0.00 \pm \\
0.00\end{array}$ & $\begin{array}{r}21.30 \pm \\
0.58^{\mathrm{h}, \mathrm{h}^{\prime}}\end{array}$ & $\begin{array}{c}0.00 \pm \\
0.00\end{array}$ & $\begin{array}{c}0.00 \pm \\
0.00\end{array}$ & $\begin{array}{c}15.30 \pm \\
0.58^{\mathrm{h}, \mathrm{e}^{\prime}} \\
\end{array}$ \\
\hline \multirow{3}{*}{$\mathrm{Co}(\mathrm{HL})_{2} \mathrm{Cl}_{2}$} & 30 & $\begin{array}{c}0.00 \pm \\
0.00\end{array}$ & $\begin{array}{l}28.70 \pm \\
6.3^{\mathrm{a}, \mathrm{a}^{\prime}, c^{\prime}, \mathrm{d}^{\prime}}\end{array}$ & $\begin{array}{c}0.00 \pm \\
0.00\end{array}$ & $\begin{array}{r}29.00 \pm \\
0.00^{\mathrm{i}, \mathrm{i}^{\prime}}\end{array}$ & $\begin{array}{c}0.00 \pm \\
0.00\end{array}$ & $\begin{array}{c}0.00 \pm \\
0.00\end{array}$ & $\begin{array}{c}23.00 \pm \\
0.00^{\mathrm{i}, \mathrm{i}^{\prime}}\end{array}$ & $\begin{array}{c}0.00 \pm \\
0.00\end{array}$ & $\begin{array}{c}0.00 \pm \\
0.00\end{array}$ & $\begin{array}{c}29.00 \pm \\
0.00^{\mathrm{i}}\end{array}$ \\
\hline & 20 & $\begin{array}{c}0.00 \pm \\
0.00\end{array}$ & $\begin{array}{c}31.00 \pm \\
0.00^{a^{\prime} a^{\prime}, e^{\prime}, b^{\prime}, d^{\prime}} \\
\end{array}$ & $\begin{array}{c}0.00 \pm \\
0.00\end{array}$ & $\begin{array}{r}23.30 \pm \\
0.58^{\mathrm{j}, \mathrm{a}^{\prime}} \\
\end{array}$ & $\begin{array}{c}0.00 \pm \\
0.00\end{array}$ & $\begin{array}{c}0.00 \pm \\
0.00\end{array}$ & $\begin{array}{r}18.00 \pm \\
0.00^{\mathrm{j}, \mathrm{d}^{\prime}}\end{array}$ & $\begin{array}{c}0.00 \pm \\
0.00\end{array}$ & $\begin{array}{c}0.00 \pm \\
0.00\end{array}$ & $\begin{array}{r}24.00 \pm \\
0.00^{\mathrm{j}, \mathrm{g}^{\prime}}\end{array}$ \\
\hline & 10 & $\begin{array}{c}0.00 \pm \\
0.00\end{array}$ & $\begin{array}{c}27.30 \pm \\
0.58^{\mathrm{a}, \mathrm{a}^{\prime}, c^{\prime}, \mathrm{c}^{\prime}, \mathrm{d}^{\prime}}\end{array}$ & $\begin{array}{c}0.00 \pm \\
0.00\end{array}$ & $\begin{array}{r}20.00 \pm \\
0.00^{\mathrm{k}, c^{\prime}}\end{array}$ & $\begin{array}{c}0.00 \pm \\
0.00\end{array}$ & $\begin{array}{c}0.00 \pm \\
0.00\end{array}$ & $\begin{array}{c}13.70 \pm \\
0.58^{\mathrm{a}} \\
\end{array}$ & $\begin{array}{c}0.00 \pm \\
0.00\end{array}$ & $\begin{array}{c}0.00 \pm \\
0.00\end{array}$ & $\begin{array}{l}18.70 \pm \\
1.15^{a, e^{\prime}, d^{\prime}}\end{array}$ \\
\hline \multirow{3}{*}{$\mathrm{Ni}(\mathrm{HL})_{2} \mathrm{Cl}_{2}$} & 30 & $\begin{array}{c}0.00 \pm \\
0.00\end{array}$ & $\begin{array}{l}38.30 \pm \\
0.58^{f e^{\prime}, d^{\prime}}\end{array}$ & $\begin{array}{c}0.00 \pm \\
0.00\end{array}$ & $\begin{array}{c}40.00 \pm \\
0.00^{1}\end{array}$ & $\begin{array}{c}0.00 \pm \\
0.00\end{array}$ & $\begin{array}{c}0.00 \pm \\
0.00\end{array}$ & $\begin{array}{r}26.70 \pm \\
0.58^{\mathrm{k}, \mathrm{d}^{\prime}}\end{array}$ & $\begin{array}{c}0.00 \pm \\
0.00\end{array}$ & $\begin{array}{c}0.00 \pm \\
0.00\end{array}$ & $\begin{array}{r}21.30 \pm \\
0.58^{\mathrm{k}, \mathrm{d}^{\prime}}\end{array}$ \\
\hline & 20 & $\begin{array}{c}0.00 \pm \\
0.00\end{array}$ & $\begin{array}{c}32.60 \pm \\
0.58^{a^{\prime} a^{\prime}, e^{\prime}, b^{\prime}, b^{\prime}} \\
\end{array}$ & $\begin{array}{c}0.00 \pm \\
0.00\end{array}$ & $\begin{array}{c}34.30 \pm \\
0.58^{\mathrm{m}} \\
\end{array}$ & $\begin{array}{c}0.00 \pm \\
0.00\end{array}$ & $\begin{array}{c}0.00 \pm \\
0.00\end{array}$ & $\begin{array}{c}20.00 \pm \\
0.00^{1, h^{\prime}}\end{array}$ & $\begin{array}{c}0.00 \pm \\
0.00\end{array}$ & $\begin{array}{c}0.00 \pm \\
0.00\end{array}$ & $\begin{array}{c}17.30 \pm \\
0.58^{\mathrm{a}, e^{\prime}}\end{array}$ \\
\hline & 10 & $\begin{array}{c}0.00 \pm \\
0.00\end{array}$ & $\begin{array}{c}26.70 \pm \\
0.58^{\mathrm{a}, \mathrm{a}^{\prime}, \mathrm{c}^{\prime}, \mathrm{c}^{\prime}, \mathrm{d}^{\prime}}\end{array}$ & $\begin{array}{c}0.00 \pm \\
0.00\end{array}$ & $\begin{array}{l}27.70 \pm \\
0.58^{\mathrm{aa}^{\mathrm{a}, \mathrm{f}^{\prime} \mathrm{i}^{\prime}}}\end{array}$ & $\begin{array}{c}0.00 \pm \\
0.00\end{array}$ & $\begin{array}{c}0.00 \pm \\
0.00\end{array}$ & $\begin{array}{c}15.30 \pm \\
0.58^{\mathrm{m}}\end{array}$ & $\begin{array}{c}0.00 \pm \\
0.00\end{array}$ & $\begin{array}{c}0.00 \pm \\
0.00\end{array}$ & $14.00 \pm$ \\
\hline \multirow[t]{3}{*}{ Trimethoprim } & 30 & $\begin{array}{c}0.00 \pm \\
0.00\end{array}$ & $\begin{array}{c}35.00 \pm \\
0.00^{\mathrm{a}, \mathrm{a}, \mathrm{e}^{\prime}, \mathrm{d}^{\prime} \mathrm{d}^{\prime}}\end{array}$ & $\begin{array}{c}19.30 \pm \\
0.58^{\mathrm{g}}\end{array}$ & $\begin{array}{r}23.30 \pm \\
0.58^{\text {n,a }}\end{array}$ & $\begin{array}{c}0.00 \pm \\
0.00\end{array}$ & $\begin{array}{c}0.00 \pm \\
0.00\end{array}$ & $\begin{array}{c}23.00 \pm \\
0.00^{\text {n,i }}\end{array}$ & $\begin{array}{c}0.00 \pm \\
0.00\end{array}$ & $\begin{array}{c}0.00 \pm \\
0.00\end{array}$ & $\begin{array}{c}24.70 \pm \\
0.58^{\mathrm{m}, \mathrm{g}^{\prime}}\end{array}$ \\
\hline & 20 & $\begin{array}{c}0.00 \pm \\
0.00\end{array}$ & $\begin{array}{c}30.30 \pm \\
0.58^{\mathrm{a}, \mathrm{a}^{\prime} \mathrm{e}^{\prime}, \mathrm{b}^{\prime}, \mathrm{d}^{\prime}}\end{array}$ & $\begin{array}{c}14.30 \pm \\
0.58^{\mathrm{h}}\end{array}$ & $\begin{array}{c}18.70 \pm \\
0.58^{\circ, c^{\prime}}\end{array}$ & $\begin{array}{c}0.00 \pm \\
0.00\end{array}$ & $\begin{array}{c}0.00 \pm \\
0.00\end{array}$ & $\begin{array}{c}18.30 \pm \\
0.58^{\circ, d^{\prime}}\end{array}$ & $\begin{array}{c}0.00 \pm \\
0.00\end{array}$ & $\begin{array}{c}0.00 \pm \\
0.00\end{array}$ & $\begin{array}{l}21.30 \pm \\
0.58^{\mathrm{n}, \mathrm{d}^{\prime}}\end{array}$ \\
\hline & 10 & $\begin{array}{c}0.00 \pm \\
0.00\end{array}$ & $\begin{array}{c}27.00 \pm \\
0.00^{\mathrm{a}, \mathrm{a}, \mathrm{a}^{\prime}, \mathrm{c}^{\prime}, \mathrm{d}^{\prime}}\end{array}$ & $\begin{array}{l}9.30 \pm \\
0.58^{\mathrm{a}, \mathrm{a}^{\prime}}\end{array}$ & $\begin{array}{c}15.00 \pm \\
0.00^{p, e^{\prime}}\end{array}$ & $\begin{array}{c}0.00 \pm \\
0.00\end{array}$ & $\begin{array}{c}0.00 \pm \\
0.00\end{array}$ & $\begin{array}{c}13.70 \pm \\
0.58^{\mathrm{a}}\end{array}$ & $\begin{array}{c}0.00 \pm \\
0.00\end{array}$ & $\begin{array}{c}0.00 \pm \\
0.00\end{array}$ & $\begin{array}{l}18.00 \pm \\
0.00^{\mathrm{a}, \mathrm{e}^{\prime}, \mathrm{d}^{\prime}}\end{array}$ \\
\hline
\end{tabular}

Table 4: In vitro antimicrobial activity of the schiff base ligand (HL) and its metal complexes.

*Different subscript letters along the same column are significantly $(\mathrm{P}<0.05)$ different. 
Transition Metal Complexes of Schiff Base Ligand Derived from Trimethoprim with Cyclohexanone: Synthesis, Characterization, Antimicrobial and Computational Studies

\begin{tabular}{|c|c|c|c|c|c|}
\hline \multirow{2}{*}{$\begin{array}{c}\text { Compounds/ } \\
\text { concentration }(\mu \mathrm{l} / \mathrm{ml})\end{array}$} & \multicolumn{5}{|c|}{ Organisms } \\
\hline & $\begin{array}{l}\text { Streptococcus } \\
\text { pyogenes }\end{array}$ & $\begin{array}{l}\text { Bacillus } \\
\text { subtilis }\end{array}$ & $\begin{array}{c}\text { Corynebacteria } \\
\text { species }\end{array}$ & $\begin{array}{c}\text { Shigella } \\
\text { dysenteriae }\end{array}$ & $\begin{array}{l}\text { Candida } \\
\text { albicans }\end{array}$ \\
\hline \multicolumn{6}{|l|}{ HL } \\
\hline 10 & - & - & - & - & - \\
\hline 8 & - & - & - & - & - \\
\hline 6 & - & + & - & + & + \\
\hline 4 & - & + & + & + & + \\
\hline 2 & + & + & + & + & + \\
\hline \multicolumn{6}{|l|}{$\mathrm{Mn}(\mathrm{HL}) \mathrm{Cl}_{2}$} \\
\hline 10 & - & - & - & - & - \\
\hline 8 & - & - & - & - & - \\
\hline 6 & - & - & - & + & - \\
\hline 4 & - & + & + & + & + \\
\hline 2 & + & + & + & + & + \\
\hline \multicolumn{6}{|l|}{$\left[\mathrm{Fe}(\mathrm{HL}) \mathrm{Cl}_{2}\right] \mathrm{Cl}$} \\
\hline 10 & - & & - & - & - \\
\hline 8 & - & & - & - & - \\
\hline 6 & - & & - & - & - \\
\hline 4 & - & & + & - & + \\
\hline 2 & + & & + & + & + \\
\hline \multicolumn{6}{|l|}{$\mathrm{Co}(\mathrm{HL}) \mathrm{Cl}_{2}$} \\
\hline 10 & - & & - & - & - \\
\hline 8 & - & & - & - & - \\
\hline 6 & - & & - & - & - \\
\hline 4 & - & & - & + & + \\
\hline 2 & + & & + & + & + \\
\hline \multicolumn{6}{|l|}{$\mathrm{Ni}(\mathrm{HL}) \mathrm{Cl}_{2}$} \\
\hline 10 & - & & - & - & - \\
\hline 8 & - & & - & - & - \\
\hline 6 & - & & - & - & - \\
\hline 4 & - & & - & + & + \\
\hline 2 & + & & + & + & + \\
\hline \multicolumn{6}{|l|}{ Trimethoprim } \\
\hline 10 & - & & - & - & - \\
\hline 8 & - & & - & - & - \\
\hline 6 & - & & - & - & - \\
\hline 4 & - & & + & + & + \\
\hline 2 & + & & + & + & + \\
\hline
\end{tabular}

Table 5: Minimum inhibitory concentration (MIC) of the ligand (HL) and its complexes.

Key: +: Turbid (there is growth); -: Clear (No Growth).

the activity, which are solubility, conductivity and bond length between the metal and the ligand [37]. The MIC and MBC values of the compounds were found to be from $4-10 \mu \mathrm{g} / \mathrm{ml}$, with [Fe(HL) $\mathrm{Cl}_{2}$ ]Cl showed an $\mathrm{MBC}$ value of $>10$.

\section{Computational studies}

In order to gain more insight into the molecular properties of the Ligand and the complexes, density functional theory (DFT) approach was used to elucidate properties such as: HOMO - LUMO energy gaps, the Laplacian of the electron density of the ligand, the Wiberg bond order and bond polarity of some diagnostic bonds in the complexes. In practice, the molecular structures of the ligand and the complexes were drawn and pre-optimized with AVOGADRO software; the molecular properties were then examined using ORCA at the BP/RI def2-SVP level of theory [38,39].

\section{Results and Discussion}

The pre-optimized structure of the Ligand as well as the HOMO -LUMO energy gap are shown in figure $8 \mathrm{a}$ and $8 \mathrm{~b}$ respectively. Since two moles equivalent of the ligand was used in the formation of the complexes, one might expect coordination of the metals through the imine $\mathrm{N}(\mathrm{N} 22)$ and the aromatic N (N17) or through the free 
Transition Metal Complexes of Schiff Base Ligand Derived from Trimethoprim with Cyclohexanone: Synthesis, Characterization, Antimicrobial and Computational Studies

\begin{tabular}{|c|c|c|c|c|c|}
\hline \multirow{2}{*}{$\begin{array}{c}\text { Compounds/ } \\
\text { Concentration }(\mu \mathrm{L} / \mathrm{ML})\end{array}$} & \multicolumn{5}{|c|}{ Organisms } \\
\hline & $\begin{array}{c}\text { Streptococcus } \\
\text { pyogenes }\end{array}$ & $\begin{array}{l}\text { Bacillus } \\
\text { subtilis }\end{array}$ & $\begin{array}{c}\text { Corynebacteria } \\
\text { species }\end{array}$ & $\begin{array}{c}\text { Shigella dys- } \\
\text { enteriae }\end{array}$ & $\begin{array}{l}\text { Candida } \\
\text { albicans }\end{array}$ \\
\hline \multicolumn{6}{|l|}{ HL } \\
\hline 10 & - & - & - & - & - \\
\hline 8 & - & + & - & + & + \\
\hline 6 & - & + & - & + & + \\
\hline 4 & - & + & + & + & + \\
\hline 2 & + & + & + & + & + \\
\hline \multicolumn{6}{|l|}{$\operatorname{Mn}(\mathrm{HL}) \mathrm{Cl}_{2}$} \\
\hline 10 & - & - & - & - & - \\
\hline 8 & - & + & - & - & - \\
\hline 6 & - & + & - & + & + \\
\hline 4 & - & + & + & + & + \\
\hline 2 & + & + & + & + & + \\
\hline \multicolumn{6}{|l|}{$\left[\mathrm{Fe}(\mathrm{HL}) \mathrm{Cl}_{2}\right] \mathrm{Cl}$} \\
\hline 10 & - & + & - & - & - \\
\hline 8 & - & + & - & - & - \\
\hline 6 & - & + & - & - & - \\
\hline 4 & - & + & + & - & + \\
\hline 2 & + & + & + & + & + \\
\hline \multicolumn{6}{|l|}{$\mathrm{Co}(\mathrm{HL}) \mathrm{Cl}_{2}$} \\
\hline 10 & - & & - & - & - \\
\hline 8 & - & & - & - & - \\
\hline 6 & - & & - & + & - \\
\hline 4 & - & & - & + & - \\
\hline 2 & + & & + & + & + \\
\hline \multicolumn{6}{|l|}{$\mathrm{Ni}(\mathrm{HL}) \mathrm{Cl}_{2}$} \\
\hline 10 & - & . & - & - & - \\
\hline 8 & - & & - & - & - \\
\hline 6 & - & & - & - & + \\
\hline 4 & - & & - & + & + \\
\hline 2 & + & & + & + & + \\
\hline \multicolumn{6}{|l|}{ Trimethoprim } \\
\hline 10 & - & - & - & - & - \\
\hline 8 & - & + & - & - & - \\
\hline 6 & - & + & - & + & - \\
\hline 4 & - & + & + & + & + \\
\hline 2 & + & + & + & + & + \\
\hline
\end{tabular}

Table 6: Minimum bactericidal concentration (MBC) of the ligand (HL) and its complexes.

Key: +: Turbid (there is growth); -: Clear (no growth).

amino N (N19) and one aromatic N (N16 or N17). However, the electron density around the imine $\mathrm{N}(\mathrm{N} 22)$ and the free amino $\mathrm{N}$ (N19) will actually determine the coordination mode as the metals will coordinate through the $\mathrm{N}$ with the higher electron density. Figure $8 \mathrm{a}$ and $8 \mathrm{~b}$ show the Laplacian of electron density around N19 in a plane and through a line respectively. The Laplacian of electron density around N22 in a plane and through a line are shown in figure $8 \mathrm{c}$ and $8 \mathrm{~d}$ respectively. From the result obtained, it is evident that the metals will be coordinated to the bimolecular ligands through the imine Ns (N22 and the corresponding N46 in the second molecule) and the aromatic Ns (N17, and the correspond- ing N57 in the second molecule). This coordination mode is shown in the pre-optimized structures of the metal complexes in figure 9.

The HOMO - LUMO energy gaps of the complexes are also displayed in figure 10. The incorporation of the metals increases the HOMO - LUMO energy gap [i.e. from $2.4252 \mathrm{eV} \rightarrow 4,5779 \mathrm{eV}, 2.4252$ $\mathrm{eV} \rightarrow 4.7341 \mathrm{eV}, 2.4252 \mathrm{eV} \rightarrow 6.9030 \mathrm{eV}$ and $2.4252 \mathrm{eV} \rightarrow 7.2299 \mathrm{eV}$ for $\mathrm{Co}(\mathrm{Hl})_{2} \mathrm{Cl}_{2}, \mathrm{Fe}(\mathrm{Hl})_{2} \mathrm{Cl}_{3}, \mathrm{Mn}(\mathrm{HI})_{2} \mathrm{Cl}_{2}$ and $\mathrm{Ni}\left(\mathrm{Hl}_{2} \mathrm{Cl}_{2}\right.$ respectively].

Similarly, table 7 shows some bonding analysis of the complexes. The metal (M) - Nitrogen (N) and the Metal (M) - Chloride (Cl) 


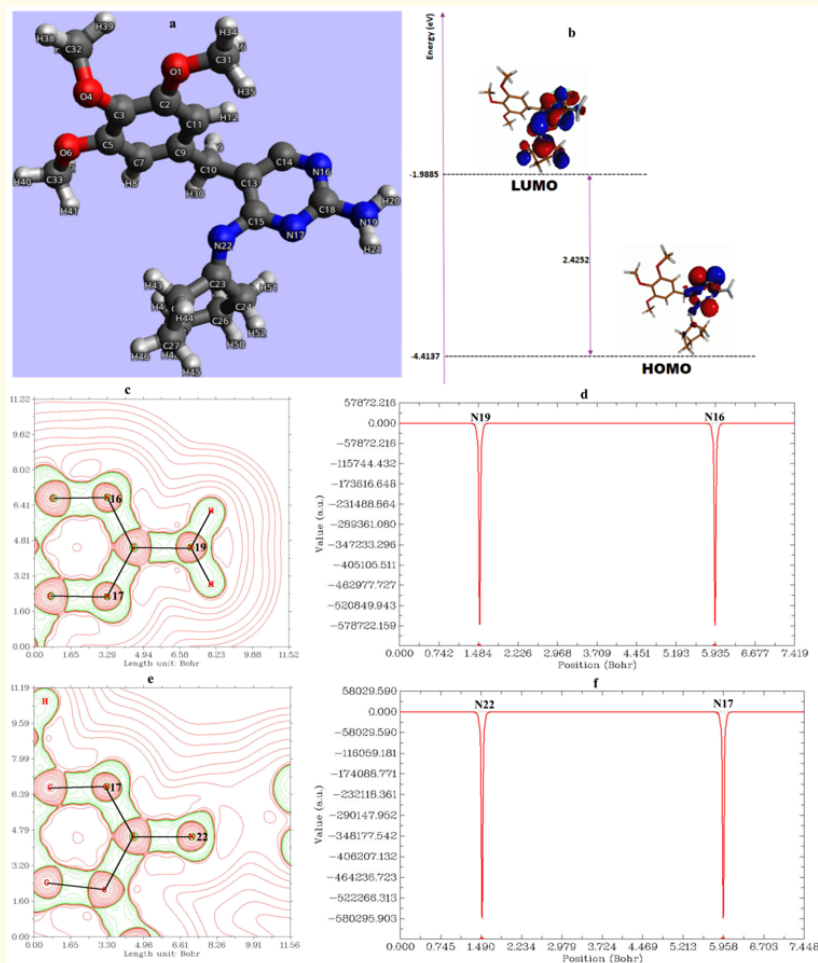

Figure 8: (a) Pre-optimized structure of the Ligand (HL) (b) HOMO - LUMO energy gap of Ligand (HL) (c) Contour line map of Laplacian of electron density of Ligand (HL) in a plane defined by N19, C18 and N16 (d) Laplacian of electron density of Ligand (HL) in a line through N19 and N16 (e) Contour line map of Laplacian of electron density of Ligand (HL) in a plane defined by N22, C15 and N17 (f) Laplacian of electron density of Ligand (HL) in a line through N22 and N17.

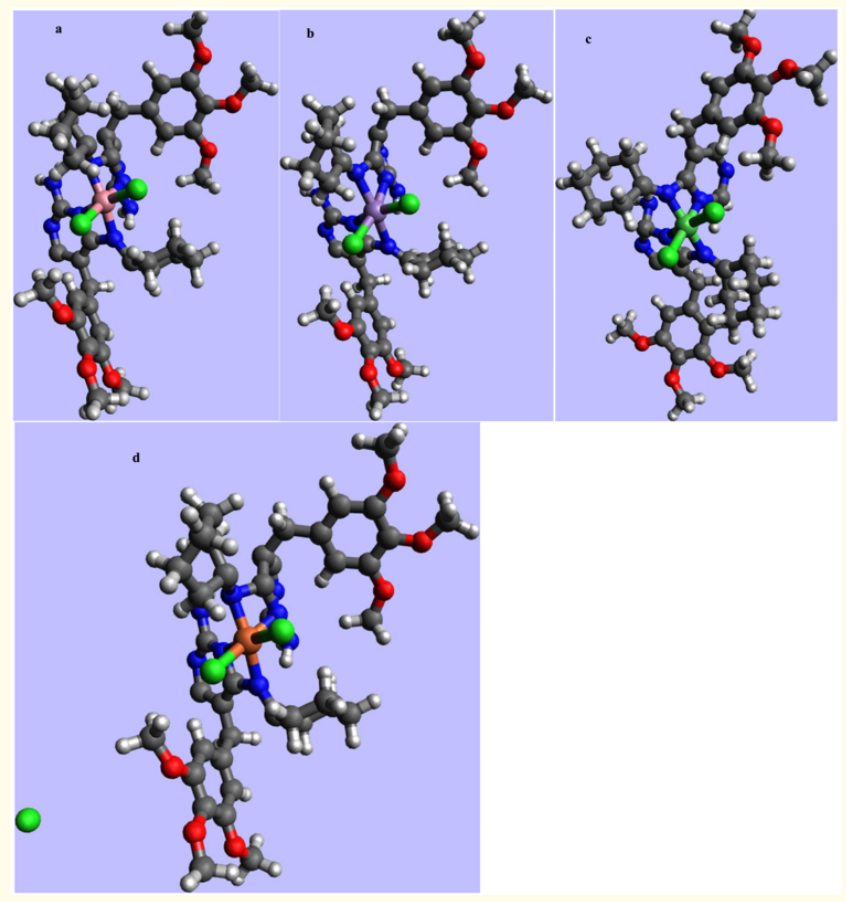

Figure 9: Pre-optimized structure of (a) $\mathrm{Co}(\mathrm{HL})_{2} \mathrm{Cl}_{2}$ (b) $\mathrm{Mn}(\mathrm{HL})_{2} \mathrm{Cl}_{2}$ (c) $\mathrm{Ni}(\mathrm{HL})_{2} \mathrm{Cl}_{2}$ (d) $\mathrm{Fe}(\mathrm{HL})_{2} \mathrm{Cl}_{3}$.

bond orders were obtained from the Wiberg-Mayer bond indices through the Natural Bond Orbital (NBO) calculation on the complexes. As seen in table 1 , the average $\mathrm{M}-\mathrm{N}$ bond order shows that

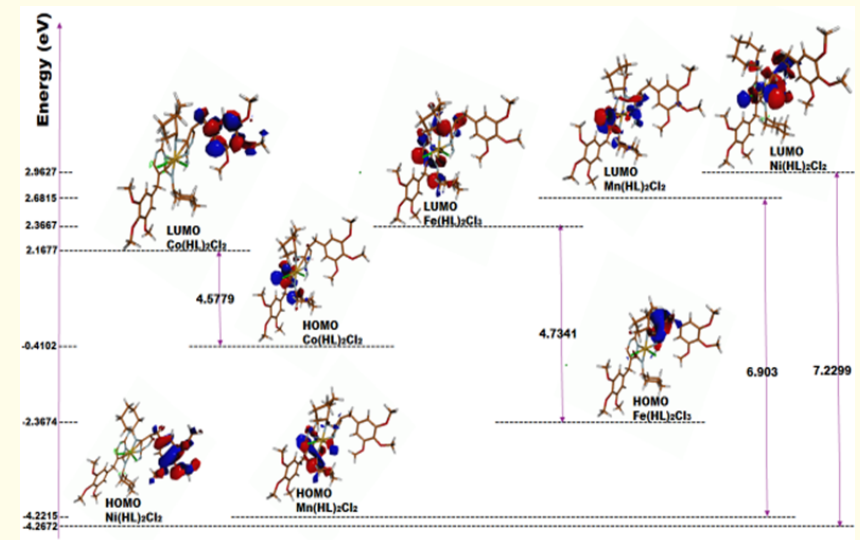

Figure 10: HOMO - LUMO energy gap of the complexes $\left[\mathrm{Co}(\mathrm{HL})_{2} \mathrm{Cl}_{2}, \mathrm{Fe}(\mathrm{HL})_{2} \mathrm{Cl}_{3}, \mathrm{Mn}(\mathrm{HL})_{2} \mathrm{Cl}_{2}\right.$ and $\left.\mathrm{Ni}(\mathrm{HL})_{2} \mathrm{Cl}_{2}\right]$.

\begin{tabular}{|c|c|c|c|c|}
\hline Type of bond & \multicolumn{4}{|c|}{ Wiberg bond order } \\
\hline & $\mathbf{C o}(\mathbf{H L})_{2} \mathbf{C l}_{2}$ & $\mathbf{F e}(\mathbf{H L})_{2} \mathbf{C l}_{3}$ & $\mathbf{N i}(\mathbf{H L})_{2} \mathbf{C l}_{2}$ & $\mathbf{M n}_{(\mathbf{H L})_{2} \mathbf{C l}_{2}}$ \\
\hline $\mathrm{M}_{85}-\mathrm{N}_{17}$ & 0.2781 & 0.3674 & 0.2645 & 0.3280 \\
\hline $\mathrm{M}_{85}-\mathrm{N}_{22}$ & 0.3678 & 0.3292 & 0.2866 & 0.3406 \\
\hline $\mathrm{M}_{85}-\mathrm{N}_{46}$ & 0.4272 & 0.5358 & 0.3357 & 0.3942 \\
\hline $\mathrm{M}_{85}-\mathrm{N}_{57}$ & 0.3557 & 0.4450 & 0.3315 & 0.3462 \\
\hline Average M-N & 0.3572 & 0.4194 & 0.3046 & 0.3523 \\
\hline $\mathrm{M}_{85}-\mathrm{Cl}_{86}$ & 0.5447 & 0.4570 & 0.4549 & 0.5186 \\
\hline $\mathrm{M}_{85}-\mathrm{Cl}_{87}$ & 0.4567 & 0.3806 & 0.4326 & 0.5065 \\
\hline Average M-Cl & 0.5007 & 0.4188 & 0.4438 & 0.5126 \\
\hline
\end{tabular}

Table 7: Wiberg bond order of some diagnostic bonds in the ligand-metal complexes.

\begin{tabular}{|c|c|c|c|c|}
\hline Bond type & $\mathrm{Co}(\mathrm{HL})_{2} \mathrm{Cl}_{2}$ & $\mathrm{Fe}(\mathrm{HL})_{2} \mathrm{Cl}_{3}$ & $\mathrm{Ni}(\mathrm{HL})_{2} \mathrm{Cl}_{2}$ & $\operatorname{Mn}(\mathrm{HL})_{2} \mathrm{Cl}_{2}$ \\
\hline Average & $\begin{array}{l}\text { Co: } 37.16 \% \\
\text { N: } 62.85 \%\end{array}$ & & & \\
\hline $\begin{array}{l}\text { Average } \\
\mathrm{M}-\mathrm{Cl}\end{array}$ & $\begin{array}{l}\text { Co: } 33.39 \% \\
\text { Cl: } 66.62 \%\end{array}$ & $\begin{array}{l}\text { Fe: } 15.46 \% \\
\text { Cl: } 84.53 \%\end{array}$ & $\begin{array}{l}\mathrm{Ni}: 34.85 \% \\
\mathrm{Cl}: 65.16 \%\end{array}$ & $\begin{array}{c}\text { Mn: } 20.28 \% \\
\text { Cl: } 79.73 \%\end{array}$ \\
\hline
\end{tabular}

Table 8: Bond polarity of Metal (M) - Nitrogen (N) and Metal (M) - Chloride (Cl) bonds in the complexes.

the metals were strongly chelated in the order: $\mathrm{Ni}<\mathrm{Mn}<\mathrm{Co}<\mathrm{Fe}$. However, the average $\mathrm{M}-\mathrm{Cl}$ bond length decreases in the order: $\mathrm{Fe}$ $-\mathrm{Cl}>\mathrm{Ni}-\mathrm{Cl}>\mathrm{Co}-\mathrm{Cl}>\mathrm{Mn}-\mathrm{Cl}$

In the same vein, the average $\mathrm{M}-\mathrm{N}$ and $\mathrm{M}-\mathrm{Cl}$ bond polarities are shown in table 8 . As seen in table 8 , the $\mathrm{M}-\mathrm{N}$ bond polarity decreases in the order: $\mathrm{Ni}-\mathrm{N}>\mathrm{Mn}-\mathrm{N}>\mathrm{Fe}-\mathrm{N}>\mathrm{Co}-\mathrm{N}$ while the $\mathrm{M}-\mathrm{Cl}$ bond polarity decreases in the order: $\mathrm{Fe}-\mathrm{Cl}>\mathrm{Mn}-\mathrm{Cl}>\mathrm{Co}-\mathrm{Cl}$ $>\mathrm{Ni}-\mathrm{Cl}$.

From all the molecular properties examined, it appears that the HOMO - LUMO energy gap has no correlation with the anti-biotic properties of the complexes. However, it seems that the presence of the $\mathrm{Cl}$ in the metal complexes influences the anti-biotic properties. Thus, the stronger the $\mathrm{M}-\mathrm{Cl}$ bond, the less active the complex as the experimental order of activity for the complexes on some selected bacterial was in agreement with the $\mathrm{M}-\mathrm{Cl}$ bond order. 


\section{Conclusion}

It could be concluded that potential metal based bactericidal have been identified. The results of the physical, antimicrobial and spectroscopic studies confirmed formation of the complexes with broad-spectrum antibacterial activity. Computational studies further revealed that $\mathrm{M}-\mathrm{Cl}$ bond is responsible for the trend in antimicrobial properties among the complexes

\section{Bibliography}

1. Zakeyah AA., et al. "Synthesis and antimicrobial studies of hydrazone derivatives of 4-[3-(2,4-difluorophenyl)-4-formyl-1Hpyrazol-1 yl]benzoic acid and 4-[3-(2,4-difluorophenyl)-4-formyl-1H-pyrazol-1-yl]benzoic acid". Bioorganic and Medicinal Chemistry Letters 28 (2018): 2914-2919.

2. Golker Z., et al. "Bacteriophage therapy: a potential solution for the antibiotic resistance crisis". Journal of Infection in Developing Countries 8.2 (2014): 129-136.

3. Friedrich MJ. "WHO survey reveals misconceptions about antibiotic resistance". The Journal of the American Medical Association 315 (2001): 242.

4. Read AF and Woods RJ. "Antibiotic resistance management". Evolution, Medicine, and Public Health1 (2014): 147.

5. Viswanatha VK. "Off-label abuse of antibiotics by bacteria". Gastrointestinal Microbiota 5.1 (2014): 3-4.

6. Willyard C. "The drug-resistance bacteria that pose the greatest health treats". Nature 543 (2017): 15.

7. Sutcliffe JA. "Improving on nature; antibiotics that target the ribosome". Current Opinion in Microbiology 8.5 (2005): 534542.

8. Robert P and Martina T. "Designing drugs that overcome antibacterial resistance: where do we stand and what should we do?" Expert Opinion on Drug Discovery 10.8 (2015): 1-20.

9. Henry FC and Frank DL R. "Waves of Resistance: Staphylococcus aureus in the Antibiotic Era". Nature Reviews Microbiology 7.9 (2009): 629-641.

10. Mulvey MR., et al. "Community-associated methicillin-resistant Staphylococcus aureus". Canada Emerging Infectious Diseases 11 (2005): 844-850.

11. Ndahi NP., et al. "Complexes of Mn(II) and Fe (III) with Schiff bases Derived from Trimethoprim with Salicyldehyde and Benzaldehyde as Potential Antimicrobial Agents". Nigerian Journal of Pharmaceutical and Biomedical Research 3.1 (2018): 53-59.

12. World Health Organization (WHO). “WHO Model List of Essential Medicines". (2014)

13. Masters PA., et al. "Trimethoprim-Sulfamethoxazole Revisited". Acta Medica International 163 (2003): 402- 410.
14. Ramlakhan S., et al. "Clinical Options for the Treatment of Urinary Tract Infections in Children". Journal of Clinical Medicines Insights Pediatrics 8 (2014): 31-37.

15. Zheng Z and Gao WT. "Synthetic Studies on Optically Active Schiff-Base Ligands Derived from Condensation of 2-Hydroxyacetophenone and Chiral Diamines". Molecules 7.7 (2002): 511-516.

16. Abdou SE., et al. "Synthesis, Characterization, and Anticancer Activity of New Metal Complexes Derived from 2-Hydroxy-3(hydroxyimino)-4-oxopentan-2-ylidene) benzohydrazide". Bioinorganic Chemistry and Applications (2015).

17. Ikechukwu PE and Peter AA. "Synthesis, Characterization, Anticancer, and Antioxidant Studies of Ru(III) Complexes of Monobasic Tridentate Schiff Bases". Bioinorganic Chemistry and Applications (2016).

18. Bauer AW., et al. "Antibiotic susceptibility testing by a standardized single disk method". American Journal of Clinical Pathology 45.4 (1966): 493-496.

19. Aderoju AO and Sherifah WM. "Synthesis, Characterization and Antimicrobial Activity of some Mixed TrimethoprimSulfamethoxazole Metal Complexese". World Applied Sciences Journal 33.2 (2015): 336-342.

20. Sunil J., et al. "Antibacterial Properties of Mn(II), Co(II), $\mathrm{Ni}(\mathrm{II})$ and $\mathrm{Zn}$ (II) Complexes Derived from Schifff Base Trimethoprim". Der Pharma Chemical 2.5 (2010): 329-336.

21. Radanovic DD., et al. "Simple Synthetic Method and Structural Characteristics of (1,3- Propanediaminetetraacetato) Cobalt(II) Complexes: Uniform Crystal Packing in A Series of Metal(II) Complexes with Propanediaminetetraacetate Ligand". Poyhedron 22.19 (2003): 2745-2753.

22. Osowole AA. "Synthesis and Characterization of Some Tetradentate Schiff Base Complexes and Their Hetroleptic Analogues". E-Journal of Chemistry 5.1 (2008): 130-135.

23. Shayma AS., et al. "Synthesis and Characterization of Mixed Ligand Complexes of 8-Hydroxyquinoline and o-hydroxybenzylidene-1-phenyl-2,3-dimethyl-4-amino-3-pyrazolin-5-onewith $\mathrm{Fe}(\mathrm{II}), \mathrm{Co}(\mathrm{II}), \mathrm{Ni}(\mathrm{II}), \mathrm{Cu}(\mathrm{II})$ ions". European Journal of Scientific Research 33 (2009): 702-709.

24. Raman N., et al. "Synthesis and Characterisation of $\mathrm{Cu}(\mathrm{II})$, $\mathrm{Ni}(\mathrm{II}), \mathrm{Mn}(\mathrm{II}), \mathrm{Zn}$ (II) and VO(II) Schiff Base Complexes Derived From o-Phenylenediamine and Acetanilide". Journal of Chemical Sciences 113.3(2001): 183-189.

25. Demirezen N., et al. "Synthesis of Trimethoprim Metal Complexes: Spectral, Electrochemical, Thermal, DNA-Binding and Surface Morphology Studies". Spectrochimica Acta Part A: Molecular and Biomolecular Spectroscopy 94 (2012): 243-255.

26. Xavier A and Srividhya N. "Synthesis and Study of Schiff Base Ligands". Journal of Chemical Technology and Biotechnology 7.11 (2014): 6-15 
27. Contini G., et al. "Infrared Study of 2-Mercaptobenzothiazole and Two of its Derivatives Adsorbed on PbS". The International Journal of Mineral Processing 51.1-4 (1997): 283-289.

28. Peter AA and Omoruyi GI. "Synthesis, Characterization, and Antibacterial Studies of Pd(II)and Pt(II) Complexes of Some Diaminopyrimidine Derivatives". Bioinorganic Chemistry and Applications 1 (2013): 1-8

29. Gulcan M., et al. "MSynthesis, Characterization and Antimicrobial Activity of a New Pyrimidine Schiff Base and its $\mathrm{Cu}(\mathrm{II})$, $\mathrm{Ni}(\mathrm{II}), \mathrm{Co}(\mathrm{II}), \mathrm{Pt}(\mathrm{II})$ and Pd(II) Complexes". The Turkish Journal of Chemistry 36 (2012): 189-200.

30. Raheem TM., et al. "Preparation, Characterization, and Antibacterial Properties of Mixed Ligand Complexes of L-leucine and Sulfamethoxazole (Antibiotic) with Mn(II),Co(II),Ni(II),C u(II),Zn(II),Cd(II)and Hg(II) ions". Journal Advances in Physics Theories and Applications 27 (2014): 8-19.

31. Al-amary HF. "Synthesis, Investigation of Some Mixed Ligand Chelates and Their Biological Activity". M.Sc. Thesis, Benghazi: Garyounis University, Libya (2014).

32. Adewuyi S., et al. "Synthesis, Spectroscopic, Surface and Catalytic Reactivity of Chitosan Supported Co(II) and Its Zerovalentcobalt Nanobiocomposite". Journal of Inorganic and Organometallic Polymers and Materials 27.1 (2016): 114 -121.

33. Adewuyi S., et al. "Zinc (II) Metal Ion Complexes of Chitosan: Toward Heterogeneous-active Catalyst for the Polymerization of Vinyl Acetate". Ife Journal of Science 17.3 (2015): 749 -754.

34. Cotton FA and Wilkinson G. "Advanced Inorganic Chemistry". $3^{\text {rd }}$ Edition, Wiley, New York (1972): 880-881.

35. Henri LKW., et al. "Synthesis and Antibacterial Studies of Schiff Base Complexes Derived from 2, 3-Diamino-Pyridine and ovanilline". Indian Journal of Chemistry 40 (2001): 999.

36. Sengupta S. K., et al. "Synthesis, Structural and Biochemical Aspects of Titanocene and Zirconocene Chelates of Acetylferrocenyl Thiosemicarbazones". Transition Metal Chemistry 23.4(1998): 349-353.

37. Devi TP and Singh RH. "Complexes of Nickel (II) with the Schiff Bases Derived from Condensation of Salicylaldehyde and bisNi (amuh)2Cl2". Journal of Chemical Education 3.2 (2010): 266-270.

38. Nikolaienko TY and Bulavin LA. "Localized orbitals for optimal decomposition of molecular properties". International Journal of Quantum Chemistry 119 (2018): 25798.

39. Nikolaienko TY., et al. "JANPA: An open source cross-platform implementation of the Natural Population Analysis on the Java platform". Computational and Theoretical Chemistry 1050 (2014): 15-22.

\section{Assets from publication with us}

- Prompt Acknowledgement after receiving the article

- Thorough Double blinded peer review

- Rapid Publication

- Issue of Publication Certificate

- High visibility of your Published work

Website: $w$ ww.actascientific.com/

Submit Article: www.actascientific.com/submission.php Email us: editor@actascientific.com

Contact us: +91 9182824667 